\title{
SYNTHESIS AND STRUCTURAL EXPLANATION OF MIXED LIGAND COMPLEXES OF SELENIUM(IV) WITH CAFFEINE AND SOME NITROGEN-BASED LIGANDS
}

\author{
FOZIAH A. AL-SAIF ${ }^{1}$, JEHAN Y. AL-HUMAIDI ${ }^{1}$, DALAL N. BINJAWHAR ${ }^{1}$, SALHA E. \\ ALOTAIBI ${ }^{1}$, MOAMEN S. REFAT ${ }^{2,3 *}$ \\ ${ }^{I}$ Department of Chemistry, College of Science, Princess Nourah bint Abdulrahman University, Riyadh 11671, KSA \\ ${ }^{2}$ Department of Chemistry, Faculty of Science, Taif University, Al-Haweiah, P.O. Box 888, Zip Code 21974, Taif, Saudi Arabia \\ ${ }^{3}$ Department of Chemistry, Faculty of Science, Port Said University, Port Said, Egypt
}

*corresponding author: msrefat@yahoo.com

Manuscript received: March 2020

\begin{abstract}
Mixed-ligand complexes of selenium(IV) ion chelating with caffeine (caf) molecule as a primary ligand and N,O donors (Lvaline (L-val); L-proline (L-pro); 2,4-diaminophenol (dap)), or nitrogen-base donors (2,2'-bipyridine (bpy) and bathophenanthroline (bphen)) as secondary ligand were prepared. These complexes were assigned based on different techniques like molar conductance, UV-Visible (UV-Vis), infrared (FT-IR), ${ }^{1} \mathrm{H}-\mathrm{NMR}$ spectroscopy, thermal analysis (TGA-DTG), X-ray diffraction (XRD), scanning (SEM) and transmission electron microscopes (TEM). The FT-IR and ${ }^{1} \mathrm{H}-\mathrm{NMR}$ spectra deduced that the caf chelate is acts as a monodentate with Se(IV) through the nitrogen atom N9, while secondary ligands (L-val, L-pro, dap, bpy and bphen) coordinated as bi-dentate ligand towards Se(IV) via NO or NN donating atoms. Dependent on the spectroscopic results, it can be confirmed that $\mathrm{Se}(\mathrm{IV})$ complexes have an octahedral geometry with general formulas $\left[\mathrm{Se}(\mathrm{caf})(\mathrm{L})(\mathrm{Cl})_{3}\right]$ (where $\mathrm{L}=\mathrm{L}$-val, $\mathrm{L}$ pro and dap) I-III and $\left[\mathrm{Se}(\mathrm{caf})\left(\mathrm{L}^{\prime}\right)(\mathrm{Cl})_{3}\right] \mathrm{Cl}$ (where $\mathrm{L}^{\prime}=$ bpy and bphen) $\mathbf{I V}$ and $\mathbf{V}$. The conductance data of the synthesized complexes revealed that the $\left[\mathrm{Se}(\mathrm{caf})(\mathrm{L})(\mathrm{Cl})_{3}\right]$ complexes have a non-electrolyte properties, while $\left[\mathrm{Se}(\mathrm{caf})\left(\mathrm{L}^{\prime}\right)\left(\mathrm{Cl}_{3}\right)_{3}\right] \mathrm{Cl}$ complex has a 1:1 electrolyte nature. TGA-DTG analysis shows that the degradation of complexes occurs between $30-800^{\circ} \mathrm{C}$. SEM, TEM, and XRD analyses revealed the particle size of the synthesized complexes. All the five complexes in this study were evaluated for their anticancer effect towards two colorectal adenocarcinoma (Caco-2) and breast cancer (Mcf-7) cell lines.
\end{abstract}

\section{Rezumat}

În acest studiu este descris modul de preparare al complecşilor de chelare ale ionului seleniu(IV) cu o moleculă de cafeină (caf) ca ligand primar și donori de N, O (L-valină (L-val); L-prolină (L-pro); 2,4-diaminofenol (dap)), sau donori bazici de azot (2,2'-bipiridină (bpy) și batofenantrolină (bfen)) ca ligand secundar. Acești complecși au fost caracterizați prin mai multe metode: conductanță molară, spectroscopie UV-Vizibil (UV-Vis), infraroșu (FT-IR), ${ }^{1}$ H-RMN, analiză termică (TGA-DTG), difracție de raze X (XRD), SEM și TEM. Spectrele FT-IR și ${ }^{1} \mathrm{H}-\mathrm{RMN}$ au evidențiat cafeina ca ligand monodentat pentru Se(IV) prin atomul de azot N9, în timp ce liganzii secundari (L-val, L-pro, dap, bpy și bphen) au acționat ca bidentați pentru Se(IV) prin atomi donori de NO sau NN. Conform datelor spectroscopice, se poate confirma că acești complecși au o geometrie octaedrică cu formule generale $\left[\mathrm{Se}(\mathrm{caf})(\mathrm{L})(\mathrm{Cl})_{3}\right]$ (unde L = L-val, L-pro \& dap) I-III și $\left[\mathrm{Se}(\mathrm{caf})\left(\mathrm{L}^{\prime}\right)(\mathrm{Cl})_{3}\right] \mathrm{Cl}(\mathrm{unde}$ L' = bpy și bphen) IV și V. Datele de conductanță ale complecșilor sintetizați au arătat că $\left[\mathrm{Se}(\mathrm{caf})(\mathrm{L})(\mathrm{Cl})_{3}\right]$ prezintă proprietăţi non-electrolitice, în timp ce complexul $\left[\mathrm{Se}(\mathrm{caf})\left(\mathrm{L}^{\prime}\right)(\mathrm{Cl})_{3}\right] \mathrm{Cl}$ are o natură electrolitică 1:1. Analiza TGA-DTG arată că degradarea complecșilor are loc între $30-800^{\circ} \mathrm{C}$. Analizele SEM, TEM și XRD au evidențiat mărimea particulelor complecșilor sintetizați. Toți cei cinci complecși din acest studiu au fost evaluați pentru efectul potențial anticanceros asupra a două linii celulare de adenocarcinom colorectal (Caco-2) și cancer de sân (Mcf-7).

Keywords: caffeine, secondary ligand, mixed-ligand, spectroscopy, anticancer agent

\section{Introduction}

Caffeine is one of the nitrogen-base ligand, also, it is one of the main alkalis that form in different types of foods and drinks that we consume in daily life [1]. Caffeine has ability to dissolve many of pharmaceutical drugs, because of it is included two aromatic rings which help in the dissolution of anti-malarial agent $[2,3]$. Surly, the caffeine molecule attached to the receptors on the heart muscle cell surface, that increasing the level of cyclic adenosine monophosphate
(cAMP) by blocking the enzyme which response to the decomposition of cAMP [4]. The caffeine compound plays an important role in the enhancement of the cisplatin anti-tumour activity [5]. Also from this reason platinum complexes were made from caffeine and studied its cytotoxic activity [6-12]. Caffeine commonly bonded through its nitrogen donor atom or via carbonyl oxygen atom that is a rarity occurs.

The metal complexes are monomeric, dimeric, several correlations are stabilized and discussed for coordination 
FARMACIA, 2021, Vol. 69, 1

of caffeine and derivatives [13]. The $\operatorname{Re}(\mathrm{I})$ [14], $\mathrm{Cu}$ (II) [15], $\mathrm{Zn}$ (II) [16], $\mathrm{Au}(\mathrm{III})$ [17], $\mathrm{Cu}(\mathrm{II})$ and $\mathrm{Zn}(\mathrm{II})$ complexes of caffeine and xanthine compounds [18, 19] have been synthesized and the structures as well as biological efficiency were assigned [20-22]. The caffeine, xanthines and theophylline organic ligands in usual neutral case are coordinated to different metal ions through $\mathrm{N}(9)$ donating atom [10-22]. Herein, the scope of this study is aimed to synthesis, biological assessment and spectroscopic characterization of some mixed ligand complexes of caffeine and nitrogen base secondary ligands e.g. L-valine (L-val), L-proline (Lpro), 2,4-diaminophenol (dap), 2,2'-bipyridine (bpy) and bathophenanthroline (bphen) towards selenium(IV) ions.

\section{Materials and Methods}

Chemical reagents and analysis

Caffeine, L-valine, L-proline, 2,4-diaminophenol dihydrochloride, 2,2'-bipyridine, selenium tetrachloride and bathophenanthrolinedisulfonic acid disodium salt hydrate in pure grade form were brought from SigmaAldrich Chemical Corporation (St. Louis-Mo-USA). The apparatus and their models used to investigate the synthesized selenium(IV) complexes can be summarized in Table I.

Table I

Apparatus used for the investigation of the synthesized complexes

\begin{tabular}{l|l}
\hline \multicolumn{1}{c|}{ Analyses } & \multicolumn{1}{c}{ Model of apparatus } \\
\hline Elemental analysis & Perkin Elmer "CHN 2400" \\
Conductance & Conductivity meter "Jenway 4010" \\
FT-IR spectra & FTIR Spectrophotometer "Bruker" \\
Electronic spectra & UV/Vis Spectrophotometer "UV2 Unicam" \\
Magnetic moment & Balance of Magnetic Susceptibility \\
${ }^{1} \mathrm{H}-\mathrm{NMR}$ & NMR spectrometer "Varian Mercury VX-300 MHz" \\
Thermogravimetric & Shimadzu analyser "TG/DTG-50H" \\
SEM & Quanta equipment "FEG 250" \\
XRD & X 'Pert PRO PANanalytical \\
TEM & "JEOL 100s" microscopy \\
\hline
\end{tabular}

Table II

The elemental analyses of the synthesized Se(IV)

\begin{tabular}{|c|c|c|c|c|}
\hline Complex & Colour & Element & Calc. & Found \\
\hline \multirow{4}{*}{ I } & \multirow{4}{*}{ White } & $\% \mathrm{C}$ & 31.50 & 31.23 \\
\hline & & $\% \mathrm{H}$ & 4.07 & 3.98 \\
\hline & & $\% \mathrm{~N}$ & 14.13 & 14.04 \\
\hline & & $\% \mathrm{Se}$ & 15.93 & 15.90 \\
\hline \multirow{4}{*}{ II } & \multirow{4}{*}{ White } & $\% \mathrm{C}$ & 31.63 & 31.44 \\
\hline & & $\% \mathrm{H}$ & 3.68 & 3.65 \\
\hline & & $\% \mathrm{~N}$ & 14.19 & 14.04 \\
\hline & & $\% \mathrm{Se}$ & 16.00 & 15.55 \\
\hline \multirow{4}{*}{ III } & \multirow{4}{*}{ Dark Red } & $\% \mathrm{C}$ & 33.45 & 33.32 \\
\hline & & $\% \mathrm{H}$ & 3.41 & 3.29 \\
\hline & & $\% \mathrm{~N}$ & 16.72 & 16.59 \\
\hline & & $\% \mathrm{Se}$ & 15.71 & 15.65 \\
\hline \multirow{4}{*}{ IV } & \multirow{4}{*}{ Pink } & $\% \mathrm{C}$ & 37.85 & 37.54 \\
\hline & & $\% \mathrm{H}$ & 3.18 & 3.12 \\
\hline & & $\% \mathrm{~N}$ & 14.71 & 14.43 \\
\hline & & $\% \mathrm{Se}$ & 13.82 & 13.76 \\
\hline \multirow{4}{*}{ V } & \multirow{4}{*}{ White } & $\% \mathrm{C}$ & 51.43 & 51.40 \\
\hline & & $\% \mathrm{H}$ & 3.51 & 3.49 \\
\hline & & $\% \mathrm{~N}$ & 11.24 & 11.20 \\
\hline & & $\% \mathrm{Se}$ & 10.57 & 10.54 \\
\hline
\end{tabular}

Synthesis of selenium(IV) mixed ligand complexes $0.195 \mathrm{~g}$ (1 mmol) of caffeine primary ligand was mixed to $\mathrm{SeCl}_{4}(1 \mathrm{mmol})$ in methanolic solvent $(50 \mathrm{~mL})$ with continuously magnetic stirrer. This stage was followed by the addition of $1 \mathrm{mmol}$ of L-valine, L-proline, 2,4diaminophenol dihydrochloride, 2,2'-bipyridine or bathophenanthrolinedisulfonic acid disodium salt hydrate secondary ligands with the molar ratio of
1:1:1 $\left(\mathrm{Se}^{4+}: \mathrm{L}^{1}: \mathrm{L}^{2}\right)$. These mixtures were refluxed for about $3 \mathrm{hrs}$ at $70-80^{\circ} \mathrm{C}$. The solid precipitates were filtrated, washed by few drops of methanol solvent, and dried over under vacuum. Yields of solid selenium(IV) complexes are within $73-75 \%$ range with higher melting point above $250^{\circ} \mathrm{C}$. The elemental analysis (Calc./Found) data of the synthesized Se(IV) complexes are presented in Table II.

Biological tests

The biological assessments of synthesized selenium(IV) complexes were scanned dependent on the disc diffusion method [23]. The bacterial strains used in this study are Klebsiella, Escherichia coli, Staphylococcus aureus and Staphylococcus epidermidis. The cytotoxic test which applied on the five Se(IV) complexes were performed against colorectal adenocarcinoma Caco-2 and breast cancer MCF-7 cancer cell lines using neutral red uptake assay [24].

\section{Results and Discussion}

Micro analytical and conductance measurements The synthesized selenium(IV) mixed ligand complexes were isolated in solid state forms, soluble in selected organic solvents (dimethylformamide (DMF) and dimethylsulfoxide (DMSO)) with gently warming. The lower data $\left(2-12 \mathrm{~cm}^{2} / \mathrm{ohm} \mathrm{x} \mathrm{mol}\right)$ of observed molar conductance in DMSO regarding $\left[\mathrm{Se}(\mathrm{caf})(\mathrm{L})(\mathrm{Cl})_{3}\right.$ ] complexes I-III (where L = L-val, L-pro and dap) indicates the non-electrolyte nature [25], while the molar conductance values of $\left[\mathrm{Se}(\mathrm{caf})\left(\mathrm{L}^{\prime}\right)(\mathrm{Cl})_{3}\right] \mathrm{Cl}$ 
(where $L^{\prime}=$ bpy \& bphen) IV and $\mathbf{V}$ complexes at 34 and $42 \mathrm{~m}^{2} / \mathrm{ohm} \times \mathrm{mol}$, respectively confirmed the electrolytic behaviour because of the located of one chloride ion outside the coordination sphere [25]. The elemental analysis \%carbon, \%hydrogen and $\%$ nitrogen as well as the percentage of selenium metal were in good agreement with the proposed of general formulas (Figure 1) concerning the synthesized complexes as mentioned before. As usual, all prepared selenium(IV) complexes have diamagnetic properties according to their electron configuration.

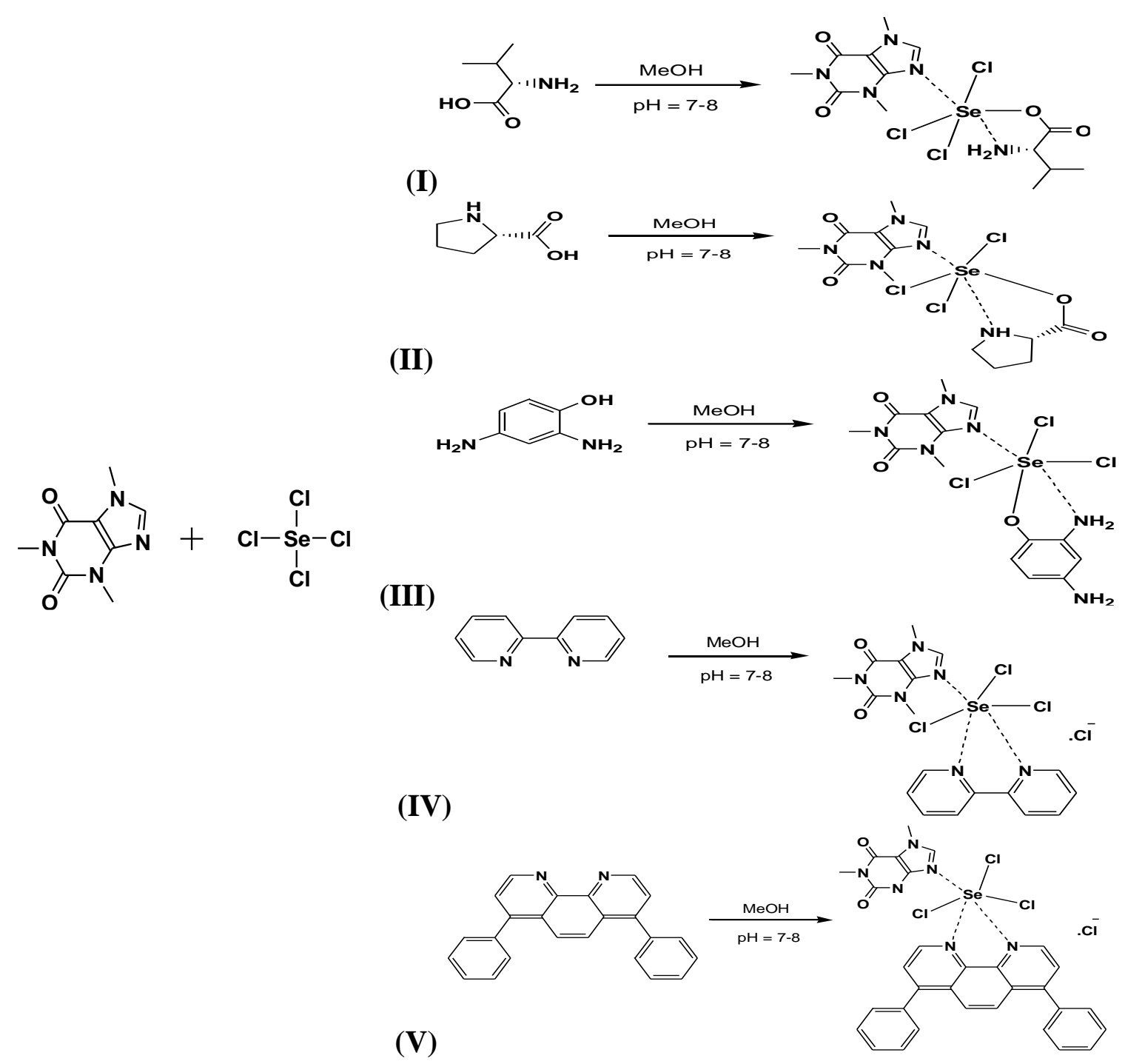

Figure 1.

Suggested structures of synthesized selenium(IV) complexes

\section{Infrared spectral studies}

The FTIR spectra of the free primary (caf) and secondary ligands (L-val, L-pro, dap, bpy and bphen) as well as their selenium(IV) complexes were scanned as shown in Figure 2, also the assignments of distinguish infrared frequencies are summarized in Table III. The vibration spectra of caffeine carbonyl group in case of Se(IV) complexes I-V exhibit an absorption band with strong intensity at $1699-1712 \mathrm{~cm}^{-1}$ range due to $v(\mathrm{CO})$ asymmetric, and the another strong band at the $1661 \mathrm{~cm}^{-1}$ attributed to $v(\mathrm{CO})$ stretching symmetry. These vibration bands are observed in the same wavenumbers compared with the free caffeine ligand, this assigned to that oxygen of carbonyl group don't sharing in the selenium(IV) complexation. The stretching $v(\mathrm{C}=\mathrm{N})$ band is shifted to lower wavenumbers at $1548-1566 \mathrm{~cm}^{-1}$ in comparable with the free caf ligand $\left(1658 \mathrm{~cm}^{-1}\right)$. This confirm the chelation of the caffeine via the nitrogen atom in position $\mathrm{N}(9)$ [26]. An essential infrared spectral band at $\sim 3400 \mathrm{~cm}^{-1}$ for the $\left[\mathrm{Se}(\mathrm{caf})(\mathrm{L})(\mathrm{Cl})_{3}\right]$ complexes I-III due to the $v(\mathrm{OH})$ stretching vibration of the $-\mathrm{COOH}$ and $-\mathrm{OH}$ groups of L-val, L-pro and dap secondary ligands are disappear. This result revealed that the complex formation occurs through the deprotonation of the hydroxyl group of L-val, L-pro and dap moieties. In the infrared spectra of the free L-val, L-pro and dap ligands, the $v(\mathrm{CO})$ frequencies are observed in the $1171-1198 \mathrm{~cm}^{-1}$ 
range, this band is shifted to lower wavenumber in the $1026-1034 \mathrm{~cm}^{-1}$ region, indicating the coordination through its nitrogen and oxygen atoms as uni-negative. In case of selenium(IV) complexes I-III, the stretching vibration $v(\mathrm{NH})$ of $-\mathrm{NH}_{2}$ group is observed in the $3118-2950 \mathrm{~cm}^{-1}$ range in comparison with the Lval, L-pro and dap ligands (3036 - $\left.3149 \mathrm{~cm}^{-1}\right)$. This lower shift suggests the coordination of nitrogen atom of amino group towards selenium metal ion. The existing absorption bands at $1480-1496 \mathrm{~cm}^{-1}$ and $1279-1293 \mathrm{~cm}^{-1}$ in case of complexes I and II are assigned to $v_{\mathrm{as}}(\mathrm{COO})$ and $v_{\mathrm{s}}(\mathrm{COO})$ respectively, in present study the difference frequencies $\Delta v$ are much greater than the ionic complexes $\left(200 \mathrm{~cm}^{-1}\right)(\Delta v=$ $\left.v_{\mathrm{as}} \mathrm{COO}-v_{\mathrm{s}} \mathrm{COO}\right)$ suggesting the uni-dentate binding of carboxylato group [26]. The weak to medium intensities bands appeared in the $609-618 \mathrm{~cm}^{-1}$ and $495-419 \mathrm{~cm}^{-1}$ region and can be assigned to the stretching vibrations of $v(\mathrm{M}-\mathrm{O})$ and $v(\mathrm{M}-\mathrm{N})$ bands respectively [26].

Regarding the $\left[\mathrm{Se}(\mathrm{caf})\left(\mathrm{L}^{\prime}\right)(\mathrm{Cl})_{3}\right] \mathrm{Cl}$ (where $\mathrm{L}^{\prime}=$ bpy \& bphen) IV \& V complexes, the spectrum of 2,2'bipyridine (bpy) and bathophenanthroline (bphen) have a strong intensity bands at $1614-1584 \mathrm{~cm}^{-1}$ and $1418-1421 \mathrm{~cm}^{-1}$ due to the $v(\mathrm{C}=\mathrm{N})$ and $v(\mathrm{C}-\mathrm{N})$ stretching vibration respectively [26]. These bands are shifted to lower wavenumber by $27-57 \mathrm{~cm}^{-1}$ and $13-21 \mathrm{~cm}^{-1}$ respectively after complexation. New bands within the range of $486-419 \mathrm{~cm}^{-1}$ in case of the spectra of complexes $\mathbf{I V}$ and $\mathbf{V}$ are assigned to $v(\mathrm{M}-\mathrm{N})$ [26], this supported the place of coordination via nitrogen atom of $\mathrm{C}=\mathrm{N}$ groups.

Table III

Distinguish infrared spectral bands of free ligands and complexes I-V

\begin{tabular}{ccccccccccccc}
\hline \multirow{2}{*}{ Assignments } & \multicolumn{1}{c}{ caf } & L-val & L-pro & dap & bpy & bphen & I & II & III & IV & V \\
\cline { 2 - 11 } & c & - & - & 3435 & - & & - & - & - & - & - \\
$v(\mathrm{O}-\mathrm{H})$ & - & 3149 & 3058 & 3036 & - & - & 3118 & 2951 & 2950 & - & - \\
$v(\mathrm{~N}-\mathrm{H})$ & & & & & & & & & 31883112 & & \\
& 1700 & 1700 & 1625 & - & - & - & 1703 & 1712 & 1699 & 1708 & 1708 \\
$v(\mathrm{C}=\mathrm{O})$ & 1659 & & & & & & 1661 & 1661 & 1661 & 1661 & 1661 \\
$\delta\left(\mathrm{NH}_{2}\right)$ & - & 1613 & 1618 & 1641 & - & & - & - & - & - & - \\
$v(\mathrm{C}=\mathrm{N})$ & 1658 & - & - & - & 1584 & 1614 & 1566 & 1548 & 1555 & 1557 & 1557 \\
$v_{\mathrm{as}}(\mathrm{COO})$ & - & - & - & - & - & - & 1496 & 1480 & - & - & - \\
$v_{\mathrm{s}}(\mathrm{COO})$ & - & - & - & - & - & - & 1293 & 1279 & - & - & - \\
$v(\mathrm{C}-\mathrm{O})$ & - & 1171 & 1171 & 1198 & - & - & 1034 & 1030 & 1026 & - & - \\
$\Delta v$ & - & - & - & - & - & - & 203 & 201 & - & - & - \\
& - & - & - & - & - & - & 618 & 609 & 609 & 618 & 609 \\
$v(\mathrm{M}-\mathrm{O})+v(\mathrm{M}-\mathrm{N})$ & & & & & & & 551 & 486 & 485 & 486 & 476 \\
& & & & & & & 495 & 419 & 429 & 428 & 419 \\
\hline
\end{tabular}
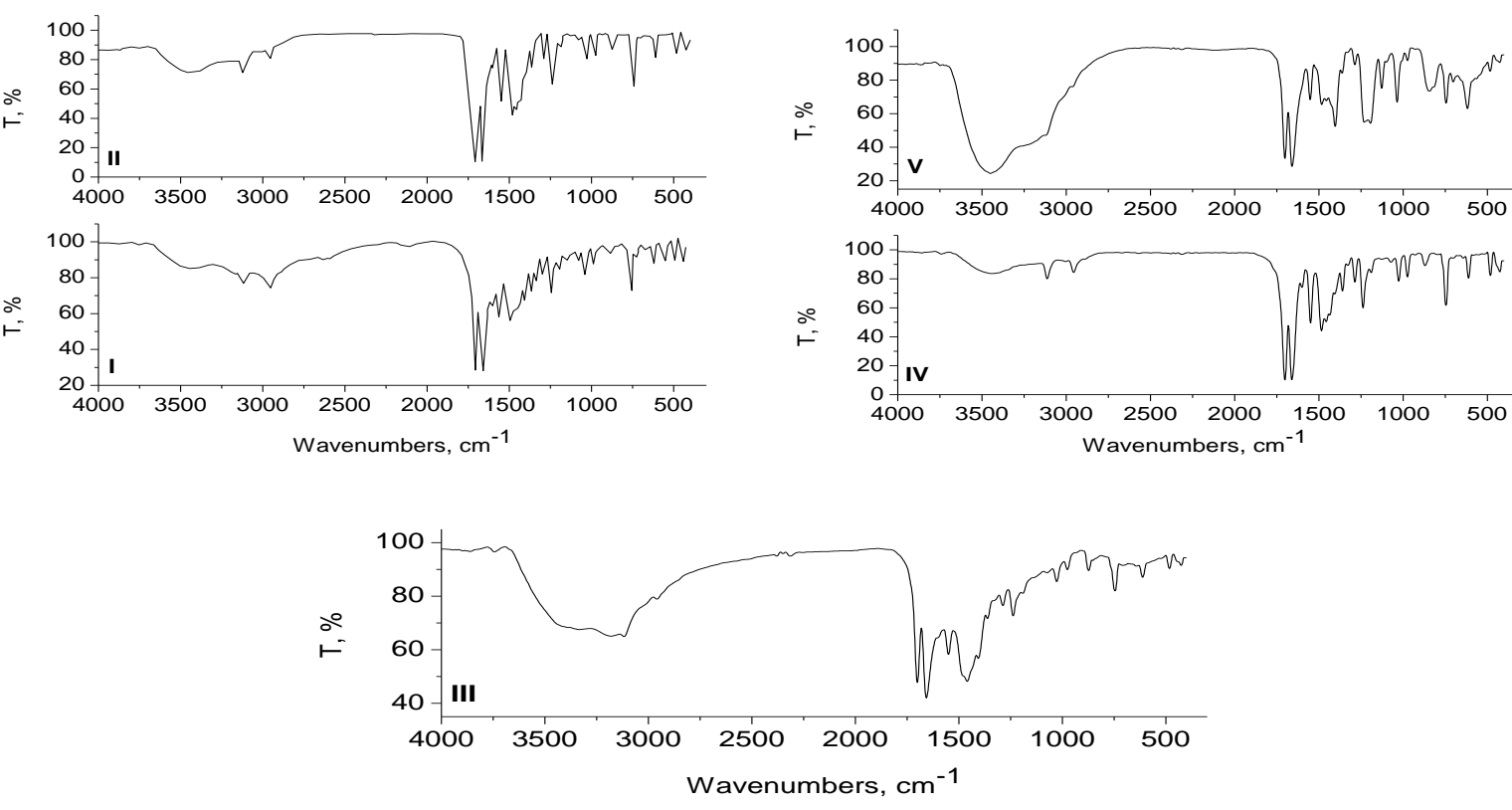

Figure 2.

Infrared spectra of Se(IV) complexes I, II, III, IV, and V 


\section{Electronic spectra studies}

The electronic absorption spectra of the free ligands caf $(275,316 \& 365 \mathrm{~nm})$, L-val (205 and $325 \mathrm{~nm})$, L-pro (280 and $332 \mathrm{~nm})$, dap (275 and $475 \mathrm{~nm}$ ), bpy (235 and $280 \mathrm{~nm})$ and bphen (280 and $320 \mathrm{~nm})$ may be assigned to $\pi \rightarrow \pi^{*}$ and $n \rightarrow \pi^{*}$ electronic transitions (Table IV) of the $\mathrm{C}=\mathrm{N}$ and $\mathrm{C}=\mathrm{O}$ groups. The absorption bands at 511 and $354 \mathrm{~nm}$ in case of complexes III and $\mathbf{V}$ are attributed to the metal-toligand or ligand-to-metal electron transfer M-L transitions $[27,28]$.

Electronic spectral data of Se(IV) complexes I-V

\begin{tabular}{c|c|c|c|c}
\hline \multirow{2}{*}{ Compounds } & \multirow{2}{*}{ Colour } & \multicolumn{3}{|c}{ Absorption bands } \\
\cline { 3 - 5 } & & $\mathrm{n}-\pi^{*}$ & $\pi-\pi^{*}$ & M-LCT \\
\hline I & White & 274 & 287 & - \\
\hline II & White & 275 & 387 & 511 \\
\hline III & Red & 286 & 286 & - \\
\hline IV & White & 274 & 311 & 354 \\
\hline V & Pink & 276 &
\end{tabular}

\section{${ }^{l} H$-NMR spectral studies}

${ }^{1} \mathrm{H}-\mathrm{NMR}$ chemical shift data of the free primary and can be listed as follows: ${ }^{1} \mathrm{HNMR}$ of caf. $\delta: 3.39(3 \mathrm{H}$, $\left.\mathrm{N} 3-\mathrm{CH}_{3}\right), 3.57\left(3 \mathrm{H}, \mathrm{N} 1-\mathrm{CH}_{3}\right), 4.00\left(3 \mathrm{H}, \mathrm{N} 7-\mathrm{CH}_{3}\right)$ and 7.53 ppm (1H, C8-H); L-val. $\delta: 3.61\left(1 \mathrm{H}, \underline{\mathrm{CH}}-\mathrm{NH}_{2}\right)$, $2.26\left(1 \mathrm{H}, \underline{\mathrm{CH}}\left(\mathrm{CH}_{3}\right)_{2}\right), 1.05\left(3 \mathrm{H}, \mathrm{CH}_{3}\right)$ and $1.00 \mathrm{ppm}$ $\left(3 \mathrm{H}, \mathrm{CH}_{3}\right)$; L-pro. $\delta: 12.80(1 \mathrm{H}, \mathrm{COOH}), 7.93(1 \mathrm{H}, \mathrm{NH})$ and 4.07 - $1.97 \mathrm{ppm}(7 \mathrm{H}$, pyrrolidine); dap. $\delta$ : $6.41-$ 6.70 (3H, Ar); bpy. $\delta: 7.12-8.59$ (8H, 2Ar); bphen. $\delta$ : 7.10-8.40 (16H, 5Ar).

${ }^{1} \mathrm{H}-\mathrm{NMR}$ spectrum of the caf ligand in DMSO- $\mathrm{d}_{6}$ has protons at 3.39, 3.57, 400 and 7.53 ppm due to $\mathrm{N} 3-\mathrm{CH}_{3}$, $\mathrm{N} 1-\mathrm{CH}_{3}, \mathrm{~N} 7-\mathrm{CH}_{3}$ (methyl groups) and $\mathrm{C} 8-\mathrm{H}$ respectively. Regarding of the selenium(IV) complexes I-V, the protons of N3- $\mathrm{CH}_{3}, \mathrm{~N} 1-\mathrm{CH}_{3}$ and $\mathrm{N} 7-\mathrm{CH}_{3}$ are practically shifted. The proton of $\mathrm{C} 8-\mathrm{H}$ was shifted to $\delta 7.98$ $8.01 \mathrm{ppm}$ in case of the Se(IV) complexes. This downfield shift was assigned to the involvement of N9 in complexity.

The ${ }^{1} \mathrm{H}-\mathrm{NMR}$ spectrum of the $\left[\mathrm{Se}(\mathrm{caf})(\mathrm{L}-\mathrm{val})(\mathrm{Cl})_{3}\right]$ complex (I) has displayed $0.90\left(3 \mathrm{H}, \mathrm{CH}_{3}\right)$ and 0.80 ppm $\left(3 \mathrm{H}, \mathrm{CH}_{3}\right), 3.19\left(3 \mathrm{H}, \mathrm{N} 3-\mathrm{CH}_{3}\right), 3.24(3 \mathrm{H}, \mathrm{N} 1-$ $\left.\mathrm{CH}_{3}\right), 3.39\left(1 \mathrm{H}, \underline{\mathrm{CH}}-\mathrm{NH}_{2}\right), 3.86\left(3 \mathrm{H}, \mathrm{N} 7-\mathrm{CH}_{3}\right)$ and 7.98 ppm $(1 \mathrm{H}, \mathrm{C} 8-\mathrm{H})$. In the ${ }^{1} \mathrm{H}-\mathrm{NMR}$ spectrum of complex I, there is downfield shift for two methyl groups of L-val. This data can be explained that the L-val is coordinated with the selenium metal ion through nitrogen of $-\mathrm{NH}_{2}$ and oxygen of carboxylate group. Furthermore, the ${ }^{1} \mathrm{H}-\mathrm{NMR}$ signals of [ $\mathrm{Se}(\mathrm{caf})(\mathrm{L}-\mathrm{pro})(\mathrm{Cl})_{3}$ ] complex (II) recorded $3.19\left(3 \mathrm{H}, \mathrm{N} 3-\mathrm{CH}_{3}\right), 3.38(7 \mathrm{H}$, pyrrolidine $), 3.85\left(3 \mathrm{H}, \mathrm{N} 7-\mathrm{CH}_{3}\right)$ and $7.98 \mathrm{ppm}(1 \mathrm{H}$, $\mathrm{C} 8-\mathrm{H})$. The absence of the signal of $-\mathrm{COOH}$ and the unfiled shift of pyrrolidine protons confirmed the acts of L-pro ligand as bidentate chelate toward selenium ion.

The ${ }^{1} \mathrm{HNMR}$ signals regarding of $\left[\mathrm{Se}(\mathrm{caf})(\mathrm{dap})(\mathrm{Cl})_{3}\right]$, $\left[\mathrm{Se}(\mathrm{caf})(\mathrm{bpy})(\mathrm{Cl})_{3}\right] . \mathrm{Cl}$ and $\left[\mathrm{Se}(\mathrm{caf})(\mathrm{bphen})(\mathrm{Cl})_{3}\right] . \mathrm{Cl}$ (III-V) complexes are $\delta: 3.37\left(3 \mathrm{H}, \mathrm{N} 3-\mathrm{CH}_{3}\right), 3.39(3 \mathrm{H}$, $\left.\mathrm{N} 1-\mathrm{CH}_{3}\right), 3.85\left(3 \mathrm{H}, \mathrm{N} 7-\mathrm{CH}_{3}\right)$ and $7.43(3 \mathrm{H}, \mathrm{Ar}$ of dap) and $8.01 \mathrm{ppm}(1 \mathrm{H}, \mathrm{C} 8-\mathrm{H}) ; 3.33\left(3 \mathrm{H}, \mathrm{N} 3-\mathrm{CH}_{3}\right), 3.38$ $\left(3 \mathrm{H}, \mathrm{N} 1-\mathrm{CH}_{3}\right), 3.85\left(3 \mathrm{H}, \mathrm{N} 7-\mathrm{CH}_{3}\right)$ and $7.98 \mathrm{ppm}(1 \mathrm{H}$, $\mathrm{C} 8-\mathrm{H})+\left(8 \mathrm{H}, \mathrm{Ar}\right.$ of bpy), and $3.19\left(3 \mathrm{H}, \mathrm{N} 3-\mathrm{CH}_{3}\right)$, $3.39\left(3 \mathrm{H}, \mathrm{N} 1-\mathrm{CH}_{3}\right), 3.86\left(3 \mathrm{H}, \mathrm{N} 7-\mathrm{CH}_{3}\right)$ and $7.98-9.17$ ppm $(1 \mathrm{H}, \mathrm{C} 8-\mathrm{H})+(16 \mathrm{H}, \mathrm{Ar}$ of bphen $)$. The prominent feature of the ${ }^{1} \mathrm{H}-\mathrm{NMR}$ spectra show downfield shifts of the $\mathrm{C} 8 \mathrm{-H}$ (caf) and protons of aromatic rings (dap, bpy and bphen) signals for the synthesized complexes. This indicates coordination through the N9, while secondary ligands (L-val, L-pro, dap, bpy and bphen) act as a bidentate ligand, coordinated to $\mathrm{Se}^{4+}$ ion through the $\mathrm{NO}$ or $\mathrm{NN}$ atoms. The ${ }^{1} \mathrm{H}-\mathrm{NMR}$ data confirm that the important chemical shifts for primary and secondary ligands have changed by coordination.

\section{Thermogravimetric measurements}

The profiles of the TGA curves (Figure 3) of the five selenium(IV) complexes I-V showed the same thermal behavior and that the mass loss of the complexes occurs in one sharp decomposition stage, this stage is in the range of $209-317^{\circ} \mathrm{C}$ at maximum differential thermogravimetric peaks DTG $\mathrm{Dax}_{\max }=283,267,254,275$ and $240^{\circ} \mathrm{C}$ with mass loss $100,100,100,100$ and $92 \%$, respectively attributed to sublimation and vaporization of the complexes [29, 30]. As for complex $\mathbf{V}$, it was found that the mass loss percentage was $92 \%$, and it can be explained that the $8 \%$ ratio is assigned to few carbon atoms as a residue after thermal cracking due to the large molecular weight and the presence of 32 carbon atoms.

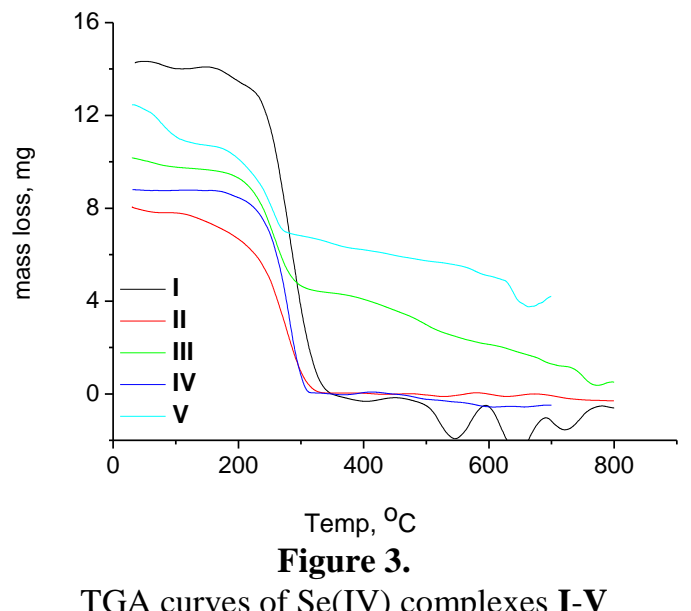

TGA curves of Se(IV) complexes I-V 
To obtain further acquaintance about the particle size of the metal complexes XRD spectra was performed as given in Figure 4. The XRD patterns indicate a crystalline behaviour for the I-IV complexes, while the XRD pattern of $\left[(\mathrm{caf})(\mathrm{bphen})(\mathrm{Cl})_{3}\right]$.Cl complex $(\mathbf{V})$ is very less crystalline phase. The estimation of $\mathrm{d}$-spacing values of reflections were resulted using the Bragg's equation $(\mathrm{n} \lambda=2 \mathrm{~d} \sin \theta)$. The average size of the particles was calculated to be $15-60 \mathrm{~nm}$ from the half-width at half-maximums of diffraction peaks by using the Debye Scherrer equation $(D=k \lambda / \beta \operatorname{Cos} \theta)$ [31], which is in good agreement with the result of the TEM image.

The morphology of the selenium metal complexes I-V have been referred by the scanning electron micrography. Figure 5 describes the SEM photographs of the synthesized Se(IV) mixed ligand complexes. It is to note that there is a homogeneous phase and a uniform matrix of the synthesized complexes in the photographs. A parallel plate package, package of parallel wide plates, group of snowballs, slices and snow block like shapes are observed in case of the $\mathrm{Se}(\mathrm{IV})$ complexes I-V respectively. The well-defined crystalline homogeneous nature of the metal complexes is observed from the XRD and SEM analysis. The TEM image of Se(IV) complexes I-V have been illustrated in Figure 6. TEM images show the complexes III and $\mathbf{V}$ have black spherical shape with average size of $15-60 \mathrm{~nm}$

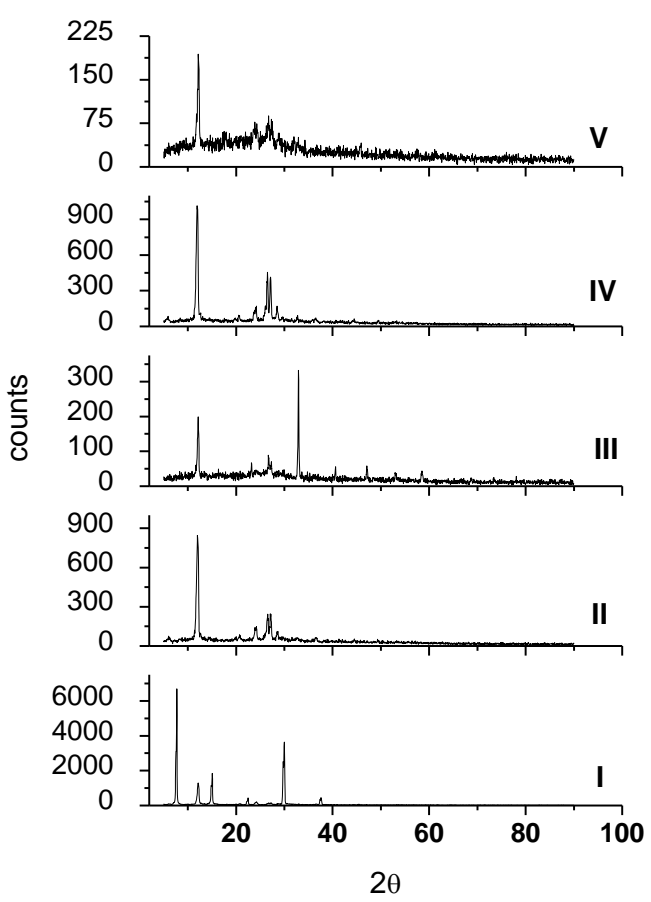

Figure 4.

XRD pattern of selenium(IV) complexes I-V
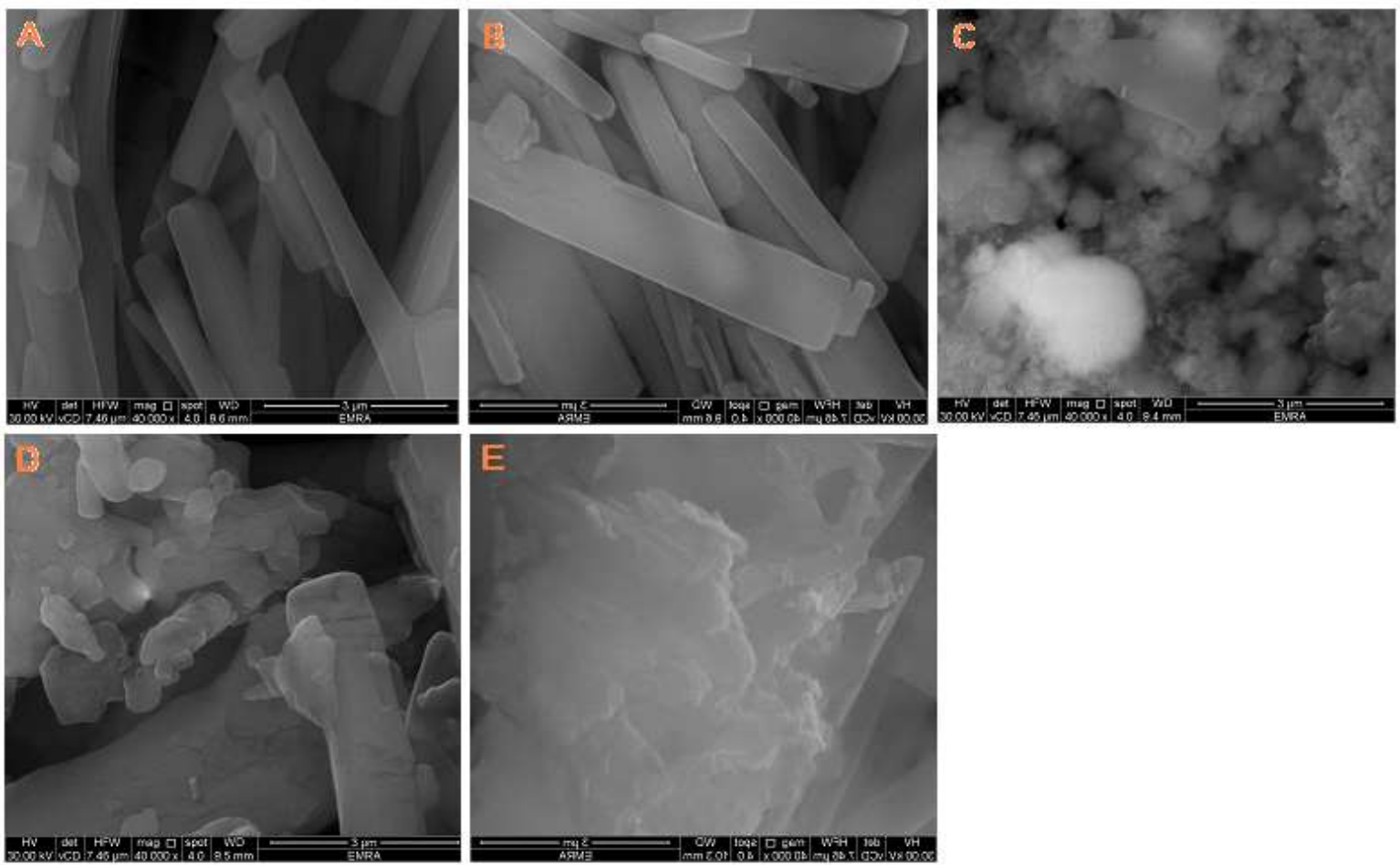

Figure 5.

SEM images of selenium(IV) complexes I-V 

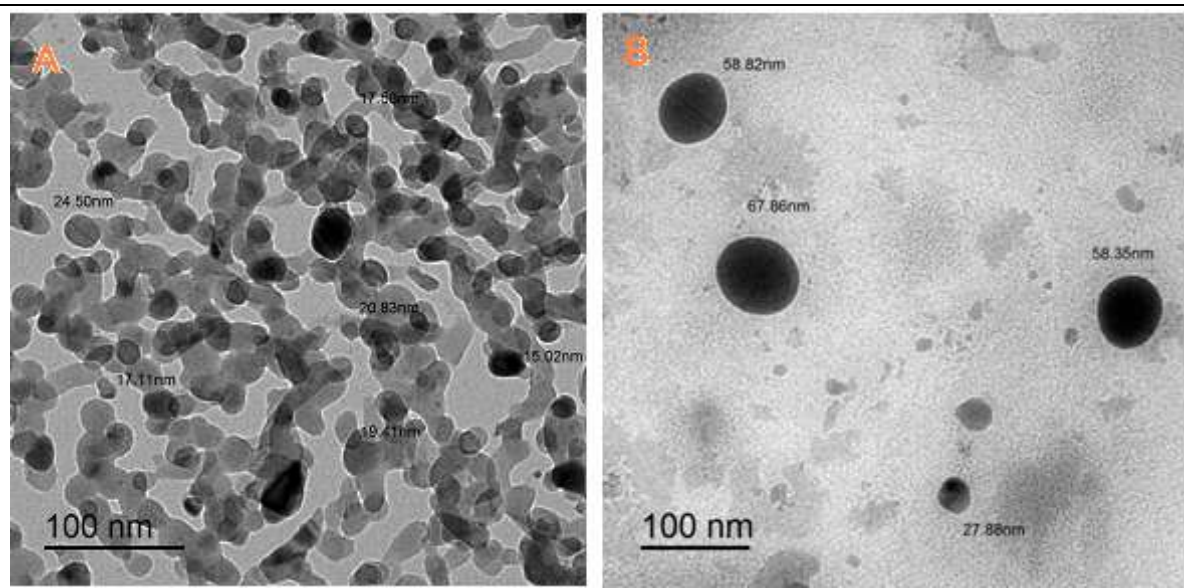

Figure 6.

TEM images of selenium(IV) complexes A: III and B: V

\section{Biological results}

In this study, a screening test for the antibacterial property for five selenium(IV) complexes $\left[\mathrm{Se}(\mathrm{caf})(\mathrm{L})(\mathrm{Cl})_{3}\right]$ (where L = L-val I, L-pro II and dap III) and $\left[\mathrm{Se}(\mathrm{caf})\left(\mathrm{L}^{\prime}\right)(\mathrm{Cl})_{3}\right] \mathrm{Cl}$ (where $\mathrm{L}^{\prime}=$ bpy IV and bphen $\mathbf{V}$ ) was done using disc diffusion method on four selected bacteria species. The results showed four complexes out of five have slightly lower antibacterial activity only on Klebsiella bacteria. The inhibition zones were $0.2,0.1,0.1$ and $0.1 \mathrm{~mm}$ for I, II, III and $\mathbf{V}$ complexes respectively, as compared with the inhibition zone of gentamicin which was $0.3 \mathrm{~mm}$.

Complex $\left[\mathrm{Se}(\mathrm{caf})(\mathrm{bpy})(\mathrm{Cl})_{3}\right] \mathrm{Cl}$ showed no antibacterial activity against all tested bacteria. All the five complexes in this study were evaluated for their cytotoxic effect against two human cancer cell lines, colorectal adenocarcinoma cell line (Caco-2) and breast cancer cell line (Mcf-7). The anticancer potency was determined by $\mathrm{IC}_{50}$ values using the neutral red assay. The negative control was represented by untreated cells with media only and the positive standard control was doxorubicin $\mathrm{HCl}(8 \mu \mathrm{g} / \mathrm{mL})$. As shown in Table $\mathrm{V}$, complexes $\mathbf{I}$, II and IV showed moderate cytotoxic activity against Caco-2 cell line only with $\mathrm{IC}_{50}$ values of 79.6, 65 and $79 \mu \mathrm{g} / \mathrm{mL}$ respectively. However, No cytotoxicity was seen in all tested complexes against breast cancer cell line (Mcf-7). The viability of the cells indicated by $\mathrm{IC}_{50}$ values were more the $100 \mu \mathrm{g} / \mathrm{mL}$.

Table V

In vitro cell viability data

\begin{tabular}{ccc}
\hline \multirow{2}{*}{ Complexes } & \multicolumn{2}{c}{ IC $50(\mu \mathrm{g} / \mathrm{mL})$} \\
\cline { 2 - 3 } & $(\mathrm{CaCo}-2)$ & $(\mathrm{MCF}-7)$ \\
\hline I & 79.6 & $>100$ \\
\hline II & 65 & $>100$ \\
\hline III & - & - \\
\hline IV & 79 & $>100$ \\
\hline V & - & $>100$ \\
\hline
\end{tabular}

$\mathrm{IC}_{50}$ values are the average of 4 replicates

\section{Conclusions}

This paper includes synthesis and characterization of mixed ligand complexes derived from caf as a primary ligand and (L-val, L-pro, dap, bpy and bphen) as a secondary ligands using selenium(IV) metal ions. The synthesized complexes have been characterized with the help of molar conductance, magnetic susceptibility measurements, thermogravimetric analysis and spectral techniques such as IR, ${ }^{1} \mathrm{H}-\mathrm{NMR}$ and electronic spectra. The synthesized complexes are also screened for their antibacterial and cytotoxic activities against colorectal adenocarcinoma and breast cell lines activities. The studies made on these complexes proposed a sixcoordinated octahedral geometry for all these complexes.

\section{Acknowledgement}

This work was funded by the Deanship of Scientific Research at Princess Nourah bint Abdulrahman University, through the Research Groups Program Grant no. (RGP-1440-0001)(2).

\section{Conflict of interest}

The authors declare no conflict of interest.

\section{References}

1. Xu W, Kim TH, Zhai D, Zhang L, Kale AA, Agrawalla BK, Cho YK, Tae Y, Make Caffeine Visible: a Fluorescent Caffeine "Traffic Light" Detector. Sci Rep., 2013; 3: 2255: 1-7.

2. Evstigneev MP, Evstigneev VP, Santiago AAH, Davies DB, Effect of a mixture of caffeine and nicotinamide on the solubility of vitamin (B2) in aqueous solution. Eur J Pharm Sci., 2006; 28(1-2): 59-66.

3. Lim LY, Go ML, Caffeine and nicotinamide enhances the aqueous solubility of the antimalarial agent halofantrine. Eur J Pharm Sci., 2000; 10(1): 17-28.

4. Greenberg JA, Dunbar CC, Schnoll R, Kokolis R, Kokolis S, Kassotis J, Caffeinated beverage intake and the risk of heart disease mortality in the elderly: a 
FARMACIA, 2021, Vol. 69, 1

prospective analysis. Am J Clin Nutr., 2007; 85(2): 392-398.

5. Roberts JJ, The mechanism of action of anti tumour platinum coordination compounds. Adv Inorg Biochem., 1981; 3: 273.

6. Cramer RE, Ho DM, van Doorne W, Ibers JA, Norton T, Kashiwagi M, Triphenylmethylphosphonium trichloro (caffeine) platinum (II) $\left[\mathrm{P}\left(\mathrm{C}_{6} \mathrm{H}_{5}\right)_{3}\left(\mathrm{CH}_{3}\right)\right]\left[\mathrm{PtCl}_{3}\right.$ (caffeine)], structure and anticancer activity. Inorg Chem., 1981; 20(8): 2457-2461.

7. Bushnell GW, Densmore RJ, Dixon KR, Purine complexes of platinum: synthesis, NMR, and crystal and molecular structures of cis-chloro(caffeine)bis (triethylphosphine)platinum(II) fluoroborate and cisbis(isocaffeine)bis(triethylphosphine)platinum (II) fluoroborate. Can J Chem., 1983; 61: 1132-1141.

8. Pneumatikakis G, 1:1 Complexes of palladium(II) and platinum(II) with caffeine and their interaction with nucleosides. Inorg Chim Acta, 1984; 93(1): 5-11.

9. Goodgame DML, Hayman PB, Riley RT, Williams DJ, Caffeine complexes of platinum(II): crystal structure of cis- $\left[\mathrm{Pt}\left(\mathrm{C}_{8} \mathrm{H}_{10} \mathrm{~N}_{4} \mathrm{O}_{2}\right)_{2} \mathrm{Cl}_{2}\right] \cdot 0.4 \mathrm{H}_{2} \mathrm{O}$. Inorg Chim Acta, 1984; 91(2): 89-93.

10. Butsch K, Elmas S, Gupta NS, Gust R, Heinrich F, Klein A, von Mering Y, Neugebauer M, Ott I, Schäfer M, Scherer H, Schurr T, Organoplatinum (II) and-palladium (II) complexes of nucleobases and their derivatives. Organometallics, 2009; 28(13): 3906-3915.

11. Shahabadi N, Moeini N, Synthesis, characterization and DNA interaction studies of a new platinum(II) complex containing caffeine and histidine ligands using instrumental and computational methods. $J$ Coord Chem., 2015; 68(16): 2871-2885.

12. Jovanovic S, Puchta R, Klisuric O, Bugarcic ZD, Crystal structure of $\mathrm{K}[\mathrm{PtCl} 3$ (caffeine)] and its interactions with important nitrogen-donor ligands. J Coord Chem., 2016; 69(5): 735-747.

13. Cozzolino D, Infrared spectroscopy as a versatile analytical tool for the quantitative determination of antioxidants in agricultural products, foods and plants. Antioxidants J., 2015; 4(3): 482-497.

14. Schweiger MJ, Beck W, Metal Complexes of Biologically Important Ligands, Part CLXXVIII. Addition of the pentacarbonylrhenium cation $\left[(\mathrm{OC})_{5} \mathrm{Re}\right]+$ to the xanthine alkaloids caffeine, theophylline, and theobromine. Z Anorg Allg Chem., 2017; 643(21): 1335-1337.

15. Jin ZM, Feng WJ, Li L, Ma XJ, Deng DS, Di- $\mu$-chlorobis [aqua (caffeine) chlorocopper (II)]. Crystallogr Commun., 2005; 61: m2631-m2633.

16. Jin ZM, Li L, Hu ML, Su H, Tong CX, Hexaaquazinc(II) bis[trichloro(3,7-di-hydro-1,3,7-trimethyl-1H-purine2,6-dione-kN9)zincate(II)] dihydrate. Crystallogr Commun., 2005; 61: m1849-m1851.
17. Ivanova B, Gold (III) complex of caffeine: Synthesis, isolation and spectroscopic characterization. Turk $J$ Chem., 2007; 31: 97-103.

18. Dubler E, Hänggi G, Schmalle H, Crystallographic evidence of preferred $\mathrm{N}(9)$-coordination of xanthine: structures of $\mathrm{CuII}(\mathrm{xan})_{2}\left(\mathrm{NO}_{3}\right)_{2}$.cntdot. $2 \mathrm{H}_{2} \mathrm{O}$, $\mathrm{CuII}(\mathrm{xan})_{2} \mathrm{Cl}_{2}$.cntdot. $2 \mathrm{H}_{2} \mathrm{O}$, and $\mathrm{ZnII}(\mathrm{xan})_{2} \mathrm{Cl}_{2}$ (xan = xanthine). Inorg Chem., 1992; 31(18): 3728- 3736.

19. Satwinder S, Jasjest K, Gurvinder S, Structure determination and anti-inflammatory activity of some purine complexes. Metal Based Drugs, 1995; 2: 735724 : 13-17.

20. Rilavarasi MN, Rao S, Udupa MR, Synthesis and characterization of copper(II) complexes of adenine and aminoacids. Chem Sci., 1997; 109(2): 79-87.

21. Hall IH, Durham RW, Tram MJ, Mueller S, Sneddon LG, Cytotoxicity and mode of action of vanada- and niobatricarbadecaboranyl monohalide complexes in human HL-60 promyelocytic leukemia cells. J Inorg Biochem., 2003; 93: 125-131.

22. Piatkowski J, Podsiadby H, Bukietynska K, The Effect of V(III)-adenine complex on yeast as a model of eukaryotic cells. J Biochem., 2007; 141(4): 545-552.

23. Bauer AW, Kirby WA, Sherris C, Turck M, Antibiotic susceptibility testing by a standardized single disc method. Am J Clin Pathology, 1996; 45(4): 493-496.

24. Repetto G, del Peso A, Zurita JL, Neutral red uptake assay for the estimation of cell viability/cytotoxicity. Nature Protocols, 2008; 3(7): 1125-1131.

25. El-Habeeb AA, Refat MS, Synthesis, structure interpretation, antimicrobial and anticancer studies of tranexamic acid complexes towards Ga (III), W(VI), Y(III) and Si(IV) metal ions. J Mol Struct., 2019; 1175: 65-72.

26. Nakamoto K, Infrared and Raman Spectra of Inorganic and Coordination Compounds Part B: Applications in Coordination, Organometallic, and Bioinorganic Chemistry, Sixth Edition, Wiley 2009; 64-68.

27. Gillam ES, Strem, An Introduction to Electronic Absorption Spectroscopy in Organic Chemistry, London, Arnold, 1957.

28. Silverstein RM, Webster FX, Kiemle DJ, Spectroscopic Introduction of Organic Compounds, $4^{\text {th }}$ Edn, 1981, 135.

29. Fujisaki H, Westmore JB, Tickner AW, Mass spectrometric study of subliming selenium. Can J Chem., 1966; 44(24): 3063-3071.

30. Lide DR, CRC Handbook of Chemistry and Physics, Edition 2007-2008. CRC Press, Taylor \& Francis, Boca Raton, FL 2007; 5-17.

31. Cullity BD, Stock SR, Elements of X-ray Diffraction, $3^{\text {rd }}$ ed., New York: Prentice Hall, 2001: 389. 